\title{
Radiocaesium in wild boars in Novohradské (Gratzen) Mountains
}

\author{
František Kouba ${ }^{1}$, Kateřina Vernerová ${ }^{2}$, Miloslav Šoch $^{2}$, Vladimír Hanzal ${ }^{5}$, \\ Lucie Filásová1, Zbyněk Semerád ${ }^{3}$, František Svoboda ${ }^{3}$, Jan Rosmus ${ }^{4}$
}

\author{
${ }^{1}$ Regional Veterinary Administration of the State Veterinary Administration for South Bohemian Region, \\ České Budějovice, Czech Republic \\ ${ }^{2}$ University of South Bohemia in České Budějovice, Faculty of Agriculture, České Budějovice, Czech Republic \\ ${ }^{3}$ State Veterinary Administration, Praha, Czech Republic \\ ${ }^{4}$ State Veterinary Institute Praha, Czech Republic \\ ${ }^{5}$ Czech University of Life Sciences Prague, Faculty of Forestry and Wood Sciences, Praha, Czech Republic
}

Received February 10, 2021

Accepted October 15, 2021

\begin{abstract}
The monitoring of radiocaesium in the ecosystems of particular areas in the Czech Republic is necessary even decades following the Chernobyl nuclear disaster. We report an evaluation of the radioactive contamination of the meat of wild boars hunted in the Novohradské (Gratzen) Mountains in the period of December 2012 to December 2019. Radionuclide ${ }^{137} \mathrm{Cs}$ is surveyed for food safety as a source of food chain contamination and a possible risk for human health. Overall, 654 samples of game meat from wild boars were analysed for ${ }^{137} \mathrm{Cs}$ activity. The ${ }^{137} \mathrm{Cs}$ legal limit of $600 \mathrm{~Bq} \cdot \mathrm{kg}^{-1}$ was exceeded in 238 samples $(36.4 \%)$ of hunted wild boar meat. Statistical analysis showed that ${ }^{137} \mathrm{Cs}$ activities measured in wild boar muscle in March reached lower values compared to the period from June till November $(P<0.05)$. Higher values were reported in September $(P<0.05)$ as well as in August $(P<0.01)$ compared to December. A significant season-based ${ }^{137} \mathrm{Cs}$ level was found $(P<0.000)$. Higher ${ }^{137} \mathrm{Cs}$ activities in wild boar in the winter season (November to April) are related to decreasing access to a naturally occurring diet with a lower ${ }^{137} \mathrm{Cs}$ content. The keepers of the wild boar in this area were ordered to comply with obligatory emergency veterinary precautions set by the Regional Veterinary Administration to analyse all hunted game meat for radiocaesium. All wild boars with an above-limit ${ }^{137} \mathrm{Cs}$ value had to be excluded from the food chain by hunting ground keepers and disposed of safely.
\end{abstract}

Caesium, Sus scrofa, venison, food chain, emergency veterinary precautions

The basic principles of the food law, part of which is the system monitoring of extraneous matter residues and contaminants, ensure a high level of protection of human health and consumer's rights. It applies to all stages of production, processing and distribution of food and feed. According to the food law, the first stage of production is primary production which accounts for hunted wild game, fishery products and harvesting of wild products. Meat originated from hunted wild game is a primary production product according to the food law.

This product is considered as food immediately after hunting. Generally, food must not be placed on the market if it is not safe (Regulation 178/2002). Radionuclide surveillance in food, of ${ }^{137} \mathrm{Cs}$ in particular, is part of the system of monitoring extraneous matter and contaminants. Already shortly after the Chernobyl nuclear disaster it was possible to detect an increase in radionuclide activity caused by this disaster in the environment of a large part of the European territory (Steinhauser et al. 2014). Mainly products from forest ecosystems (game meat, mushrooms, forest produce) generally have shown a higher ${ }^{137} \mathrm{Cs}$ content over the whole time period from the Chernobyl nuclear disaster, whereas increased levels in game meat, wild boar in particular, were detected in Czechoslovakia already in 1986. The aforementioned commodities were included in surveillance by the Radiation Monitoring Network controlled by the State Office for Nuclear Safety. State

Address for correspondence:

František Kouba

Regional Veterinary Administration of the State Veterinary

Administration for South Bohemian Region

Phone: +420387 789522

Severní 2303/9, 37010 České Budějovice, Czech Republic 
Veterinary Administration also has taken part in the research of radionuclides in raw materials of animal origin, including game meat, practically from the time of the Chernobyl nuclear disaster in 1986. Radionuclide analysing is part of the national monitoring of residues and contaminants (so called extraneous matter) in foods of animal origin; in a basic scope, radioactive contamination of foods of animal origin is monitored, as well (Škrkal et al. 2015). Early in the second decade of the $21^{\text {st }}$ century increased levels of ${ }^{137} \mathrm{Cs}$ were detected in meat samples from hunted wild boar in the Pilsen region more frequently in the Pilsen region than in the South Bohemia region of Bohemian Forest (Latini 2011). and, to a lesser extent, in the South Bohemia region of Bohemian Forest (Latini 2011). Given the fact that the number of samples exceeding the permissible limit value of $600 \mathrm{~Bq} \cdot \mathrm{kg}^{-1}$ was increasing, the State Veterinary Administration decided in collaboration with the State Office for Nuclear Safety at the end of 2012 to carry out targeted monitoring in south-western parts of the Czech Republic.

Game meat samples were taken in all districts of the South Bohemian and Pilsen regions. This special campaign resulted in a confirmation of increased sum values of radionuclides ${ }^{134} \mathrm{Cs}$ and ${ }^{137} \mathrm{Cs}$ in two areas: the Bohemian Forest (Šumava) and the Gratzen Mountains (Novohradské hory) (Kouba et al. 2013).

With the aim to determine more precisely the geographical location of areas with possible increased ${ }^{137} \mathrm{Cs}$ activity, further samples were collected at the beginning of 2013 and keepers of hunting grounds with repeatedly determined above-limit ${ }^{134} \mathrm{Cs}$ and ${ }^{137} \mathrm{Cs}$ radionuclide sum values were ordered to comply with emergency veterinary precautions according to Act No. 166/1999 on veterinary care. In compliance with the legislation, emergency veterinary precautions order the hunting ground keepers to keep proper evidence of all hunted wild boars including GPS coordinates of the hunting spot, to inform the Regional Veterinary Administration immediately after the hunting of each wild boar, and to ensure the testing of the wild boar meat intended for human consumption in an accredited laboratory to evaluate the degree of radionuclide contamination - cumulated caesium activity $\left({ }^{134} \mathrm{Cs}\right.$ and ${ }^{137} \mathrm{Cs}$ ). Hunting ground keepers were ordered to suspend each hunted wild boar meat until receiving the testing results. In case the laboratory results of the testing for cumulated caesium activity $\left({ }^{134} \mathrm{Cs}\right.$ and $\left.{ }^{137} \mathrm{Cs}\right)$ in wild boar meat were above limit, the respective hunting ground keeper was obligated to dispose of the wild boar's body and all its parts safely on an approved disposal plant in accordance with legislation. The main reasons for emergency veterinary precautions are to eliminate possible serious health hazards for the consumers.

\section{Materials and Methods}

The sampling of hunted wild boar meat for non-scheduled monitoring, within the regular plan of the monitoring of residues and contaminants in the food chain, took place in December 2012. Based on detected values exceeding the limit, continuous monitoring was ordered in designated locations.

In the period from December 2012 till December $2019,{ }^{137} \mathrm{Cs}$ activity was analysed in all hunted wild boars from the Novohradské Mountains in the South Bohemian region. In total, 654 meat samples (from skeletal muscles; shoulder, neck or forearm) were analysed.

Each sample (500 g) was accompanied by a written protocol with basic data such as the hunting ground, its register number and keeper, cadastral municipality number, game animal, its category (squeaker, sub-adult male, sow, boar), identification tag number, date of hunting, and specification of the hunting spot (GPS coordinates) (Table 5).

Sample analyses were carried out at the Food and Feed Hygiene Department - Radiology of the State Veterinary Institute Prague, by the gamma spectrum analysis method.

Quantification of radioactivity

A Marinelli container with the measured quantity of the sample to be analysed was placed on the detector body in lead shading. Generally, the measurement time is set in dependence on the requested minimal detectable activity (MDA) which is basically the only indicator that can be influenced to achieve given analysis sensitivity for standard geometry in the Marinelli container. The measurement time for wild boar meat analysis was $5000 \mathrm{~s}$. 
${ }^{137} \mathrm{Cs}$ activity was determined by gamma spectrometry system with solid state detector HPGe GEM 60 (relative $60 \%$ efficiency), GEM50P4-83 (relative 50\% efficiency) both ORTEC (AMETEK; Oak Ridge, USA) and HPGe GC5019 (CANBERRA; Atlanta, USA), also relative 50\% efficiency. The DSPec 50 analyzer with a high voltage source and the Gamma Vision program (both manufactured by ORTEC) were used. The ${ }^{137} \mathrm{Cs}$ activity was calculated from the $661.70 \mathrm{keV}$ peak using calibration standards (CZECH METROLOGY INSTITUTE; Praha, Czech Republic).

Data analysis

Determination of sample activity concentration including the minimal significant activity (MSA) and the minimal detectable activity (MDA) was accomplished by the method used by the National Radiation Protection Institute, Prague. The Microsoft Excel program (Microsoft Corporation; Redmond, USA) was used for the calculation.

Statistical evaluation of acquired data

The obtained results were statistically processed by the Microsoft Excel (Microsoft Corporation; Redmond, USA) and SPSS (IBM; Armonk, USA) programs. A $P$ value $<0.05$ was considered as significant and $P<0.01$ as highly significant.

\section{Results}

Of all the 654 wild boar meat samples collected during the monitoring period, the limit value of $600 \mathrm{~Bq} \cdot \mathrm{kg}^{-1}$ of the total sum of caesium was exceeded in 238 samples, i.e. $36.4 \%$ (Table 1). The median of the measured ${ }^{137} \mathrm{Cs}$ activity values for all monitoring periods was 358 (Table 2). The values (mean, median) during the monitoring period are shown in Fig. 1.

Table 1. Number of collected samples and representation of samples with above-limit ${ }^{137}$ Cs values from the beginning of December 2012 until the end of December 2019.

\begin{tabular}{lcccc}
\hline & $\geq 600(\mathrm{~N})$ & $<600(\mathrm{~N})$ & $\geq 600(\%)$ & $<600(\%)$ \\
\hline Novohradské Mountains location & 238 & 416 & 36.4 & 63.6 \\
\hline
\end{tabular}

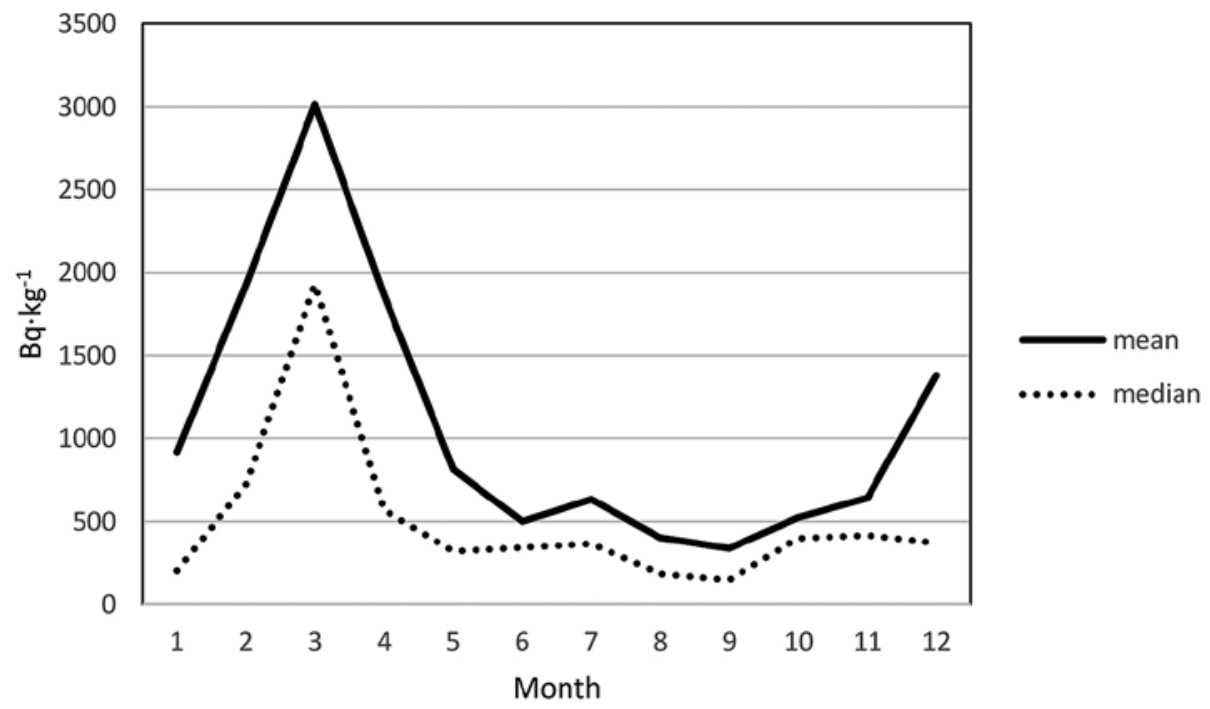

Fig. 1. Locations of involved dairy farms 
Table 2. Measured ${ }^{137} \mathrm{Cs}$ activity values from the beginning of December 2012 until the end of December 2019

\begin{tabular}{lc}
\hline Statistical indicator & Values $\left(\mathrm{Bq} \cdot \mathrm{kg}^{-1}\right)$ \\
\hline Mean & 981 \\
Median & 358 \\
Maximum & 14252 \\
\hline
\end{tabular}

Table 3. The results of a one-factor nonparametric ANOVA (Kruskal-Wallis test).

\begin{tabular}{lcc}
\hline$\chi^{2}$ & df & $P$ \\
\hline 74.81 & 11 & $<0.001$ \\
\hline
\end{tabular}

The results of a one-factor nonparametric ANOVA show that at least one month differs significantly from the others (Table 3 ), in this case, at the $1 \%$ level of significance $(P<0.001)$.

Furthermore, post hoc multiple comparisons test was performed to determine which months differed from each other significantly (Table 4). The test shows that ${ }^{137} \mathrm{Cs}$ activities measured in wild boar muscle in March reached lower values compared to the period from June till November $(P<0.05)$. In September $(P<0.05)$ as well as in August $(P<0.01)$ higher values were reported compared to December (Fig. 2).

Table 4. Dwass-Steel-Critchlow-Fligner pairwise comparisons $-{ }^{\mathrm{a}}$ values differ significantly from others.

\begin{tabular}{|c|c|c|c|c|c|c|c|}
\hline \multicolumn{2}{|c|}{ Months } & \multirow{2}{*}{$\frac{\mathrm{W}}{2.48}$} & \multirow{2}{*}{$\begin{array}{c}P \\
0.843\end{array}$} & \multicolumn{2}{|c|}{ Months } & \multirow{2}{*}{$\frac{\mathrm{W}}{-4.20}$} & \multirow{2}{*}{$\begin{array}{c}P \\
0.119\end{array}$} \\
\hline 1 & 2 & & & 4 & 8 & & \\
\hline 1 & 3 & 4.44 & 0.073 & 4 & 9 & -3.87 & 0.208 \\
\hline 1 & 4 & 2.55 & 0.817 & 4 & 10 & -2.66 & 0.773 \\
\hline 1 & 5 & 1.43 & 0.997 & 4 & 11 & -2.24 & 0.916 \\
\hline 1 & 6 & 1.08 & 1.000 & 4 & 12 & 0.35 & 1.000 \\
\hline 1 & 7 & 0.66 & 1.000 & 5 & 6 & -0.40 & 1.000 \\
\hline 1 & 8 & -0.72 & 1.000 & 5 & 7 & -0.55 & 1.000 \\
\hline 1 & 9 & -0.68 & 1.000 & 5 & 8 & -3.08 & 0.566 \\
\hline 1 & 10 & 0.90 & 1.000 & 5 & 9 & -2.77 & 0.724 \\
\hline 1 & 11 & 1.51 & 0.996 & 5 & 10 & -0.47 & 1.000 \\
\hline 1 & 12 & 3.78 & 0.241 & 5 & 11 & 0.16 & 1.000 \\
\hline 2 & 3 & 1.94 & 0.969 & 5 & 12 & 2.99 & 0.611 \\
\hline 2 & 4 & 0.23 & 1.000 & 6 & 7 & -0.02 & 1.000 \\
\hline 2 & 5 & -1.62 & 0.992 & 6 & 8 & -2.49 & 0.841 \\
\hline 2 & 6 & -2.49 & 0.839 & 6 & 9 & -2.29 & 0.902 \\
\hline 2 & 7 & -2.48 & 0.844 & 6 & 10 & 0.16 & 1.000 \\
\hline 2 & 8 & -3.27 & 0.466 & 6 & 11 & 0.93 & 1.000 \\
\hline 2 & 9 & -3.26 & 0.472 & 6 & 12 & 3.45 & 0.380 \\
\hline 2 & 10 & -2.35 & 0.885 & 7 & 8 & -2.02 & 0.958 \\
\hline 2 & 11 & -2.29 & 0.902 & 7 & 9 & -1.79 & 0.983 \\
\hline 2 & 12 & 0.47 & 1.000 & 7 & 10 & 0.07 & 1.000 \\
\hline 3 & 4 & -2.12 & 0.941 & 7 & 11 & 0.76 & 1.000 \\
\hline 3 & 5 & -4.34 & 0.090 & 7 & 12 & 3.58 & 0.318 \\
\hline 3 & 6 & -4.91 & $0.026^{\mathrm{a}}$ & 8 & 9 & 0.23 & 1.000 \\
\hline 3 & 7 & -4.72 & $0.040^{\mathrm{a}}$ & 8 & 10 & 2.71 & 0.748 \\
\hline 3 & 8 & -5.86 & $0.002^{\mathrm{a}}$ & 8 & 11 & 3.48 & 0.366 \\
\hline 3 & 9 & -5.45 & $0.006^{\mathrm{a}}$ & 8 & 12 & 6.26 & $<0.001^{\mathrm{a}}$ \\
\hline 3 & 10 & -5.15 & $0.014^{\mathrm{a}}$ & 9 & 10 & 2.43 & 0.859 \\
\hline 3 & 11 & -4.99 & $0.021^{\mathrm{a}}$ & 9 & 11 & 3.25 & 0.477 \\
\hline 3 & 12 & -2.47 & 0.848 & 9 & 12 & 5.50 & $0.006^{\mathrm{a}}$ \\
\hline 4 & 5 & -1.84 & 0.979 & 10 & 11 & 0.95 & 1.000 \\
\hline 4 & 6 & -2.63 & 0.786 & 10 & 12 & 4.10 & 0.140 \\
\hline 4 & 7 & -2.37 & 0.881 & 11 & 12 & 3.62 & 0.302 \\
\hline
\end{tabular}




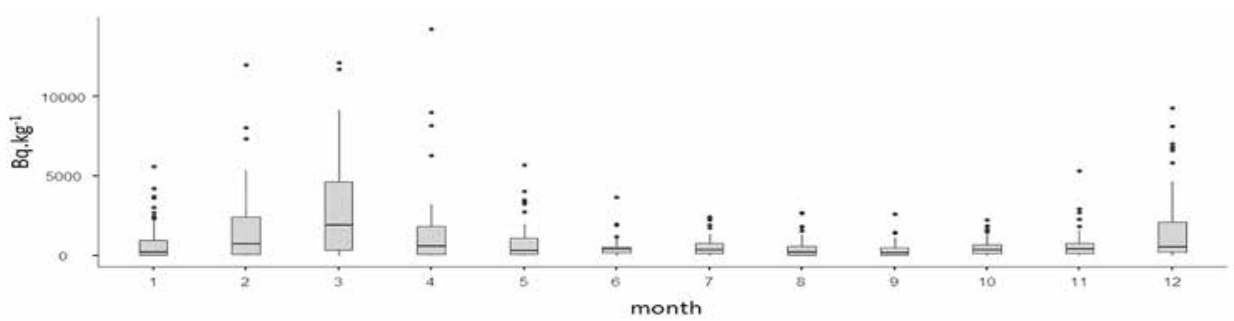

Fig. 2. Statistical distributions of dROMs values (Saphiro-Wilk test $P<0.0001$ )

Table 5. Mean values of measured ${ }^{137} \mathrm{Cs}$ activity from the beginning of December 2012 till the end of December 2019 on individual cadastral territories of the Novohradské Mountains with regard to altitude.

\begin{tabular}{|c|c|c|c|c|}
\hline $\begin{array}{c}\text { Cadastral territory } \\
\text { name }\end{array}$ & $\begin{array}{c}\text { Cadastral territory } \\
\text { number }\end{array}$ & $\begin{array}{c}\text { Cadastral territory } \\
\text { area (ha) }\end{array}$ & $\begin{array}{l}\text { Altitude } \\
\text { (m) }\end{array}$ & $\mathrm{Bq} \cdot \mathrm{kg}^{-1}$ \\
\hline Kondrač & 662739 & 623.6768 & $542-682$ & 8988 \\
\hline Benešov nad Černou & 602388 & 1240.2213 & 661 & 6942 \\
\hline Dobrá Voda u Horní Stropnice & 644170 & 131.2878 & 695 & 1930 \\
\hline Bělá u Malont & 691097 & 986.1468 & 703 & 1604 \\
\hline Konratice & 744352 & 291.4606 & 543 & 1449 \\
\hline Hojná Voda & 644188 & 352.6437 & 794 & 1348 \\
\hline Rychnov u Nových Hradů & 744361 & 1021.5996 & 585 & 1261 \\
\hline Pivonice u Pohorské Vsi & 724785 & 2053.3117 & 785 & 1233 \\
\hline Horní Stropnice & 644196 & 694.9889 & 543 & 1214 \\
\hline Velký Jindřichov & 602396 & 632.1756 & 661 & 1103 \\
\hline Dolní Př́íbraní & 724769 & 2577.6046 & 760 & 1098 \\
\hline Staré Hutě u Horní Stropnice & 644269 & 1814.5588 & 543 & 1045 \\
\hline Pohoří na Šumavě & 724807 & 2635.8193 & 910 & 847 \\
\hline Meziluží & 644234 & 721.0970 & 543 & 838 \\
\hline Slavče u Trhových Svinů & 749915 & 526.3254 & 568 & 539 \\
\hline Keblany & 749885 & 263.9913 & 568 & 522 \\
\hline Buková u Nových Hradů & 794511 & 832.9400 & 502 & 504 \\
\hline Paseky u Horní Stropnice & 644323 & 202.7384 & 543 & 474 \\
\hline Šejby & 644315 & 467.4240 & 543 & 451 \\
\hline Lužnice u Pohorské Vsi & 724777 & 860.0309 & 783 & 381 \\
\hline Dlouhá Stropnice & 644161 & 999.9830 & 543 & 307 \\
\hline Žár u Nových Hradů & 794546 & 746.6362 & 518 & 222 \\
\hline Bedřichov u Horní Stropnice & 644153 & 207.0674 & 543 & 121 \\
\hline Dobrkovská Lhotka & 749869 & 324.5018 & 568 & 114 \\
\hline Mezlesí u Trhových Svinů & 624144 & 351.7273 & 550 & 78 \\
\hline Hartunkov & 602400 & 583.4361 & 661 & 66 \\
\hline Nakolice & 706248 & 617.5675 & 541 & 59 \\
\hline Svébohy & 644293 & 1081.6551 & 529 & 46 \\
\hline Rapotice u Malont & 691160 & 621.2613 & 716 & 45 \\
\hline Veveří u Nových Hradů & 706281 & 672.4152 & 541 & 11 \\
\hline Byňov & 706191 & 2020.5599 & 541 & 7 \\
\hline Trhové Sviny & 768154 & 1483.7997 & 458 & 6 \\
\hline Pěčín u Trhových Svinů & 768235 & 622.3937 & 458 & 4 \\
\hline Čižkrajice & 624128 & 548.9696 & 550 & 3 \\
\hline Radčice u Malont & 691143 & 493.4009 & 700 & 1 \\
\hline Nové Hrady & 706256 & 531.3398 & 541 & 1 \\
\hline
\end{tabular}


The mean measured ${ }^{137} \mathrm{Cs}$ activity values also differed in individual cadastral territories of the monitored area (average altitude 502 to $910 \mathrm{~m}$ ) (Table 5). The highest average values (above 5000 Bq. $\mathrm{kg}^{-1}$ ) were measured in the cadastral territories Kodrač and Benešov nad Cernou (Fig. 3).

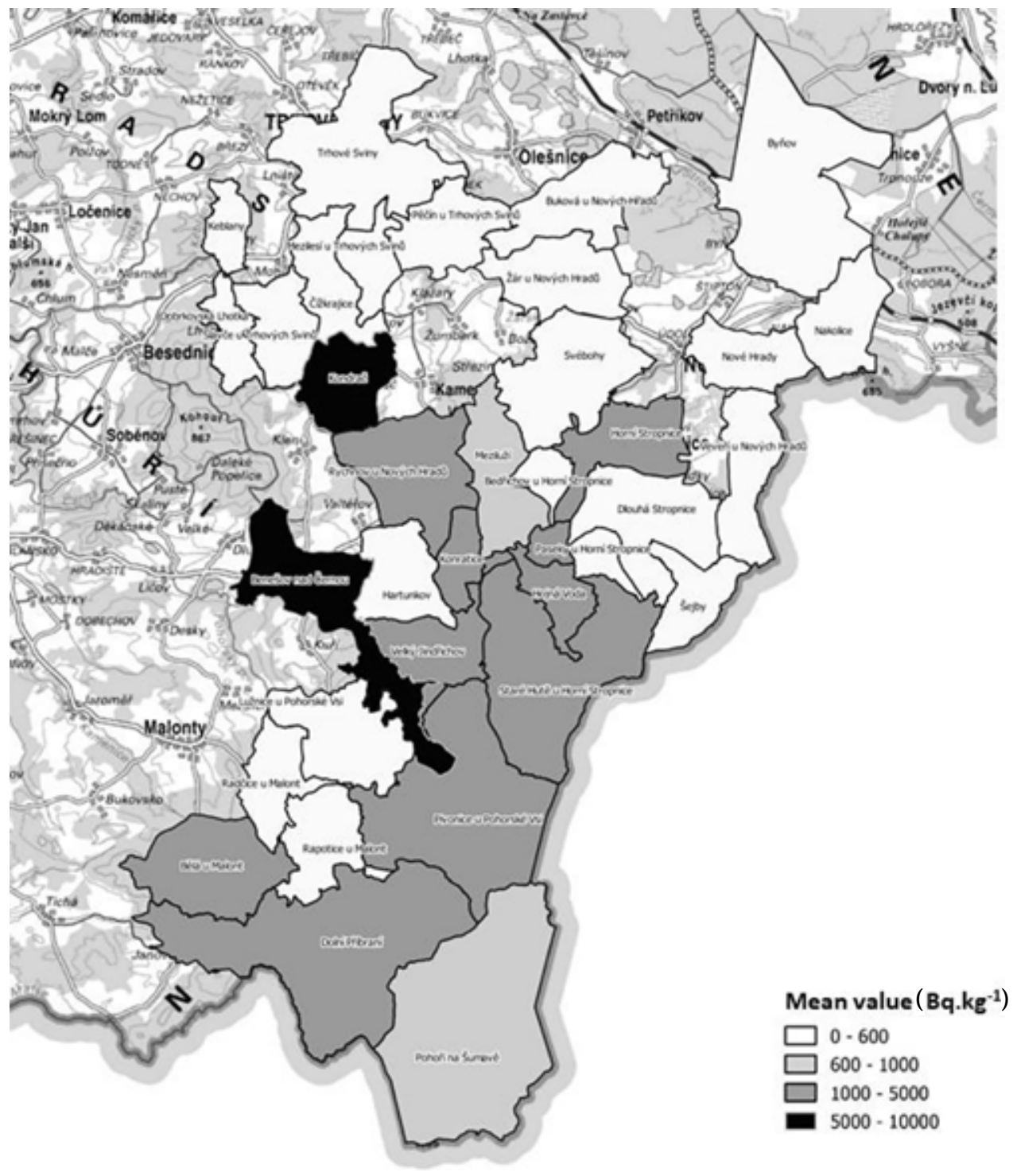

Fig. 3. Statistical distributions of PAT values (Saphiro-Wilk test $P<0.0001$ ) 
Based on the previous statistical evaluation and considering the seasonal differences in the composition of the food, the data obtained were divided into two groups according to a 6-month period, namely, the winter (November-April) and the summer (May-October) season. The aim was to statistically compare the two groups. Three independent tests (Shapiro-Wilk, Kolmogorov-Smirnov, and Anderson-Darling test) showed that the data have a normal distribution. Based on the normality of the data, independent samples $t$-test and Levene's test (Anova) were performed, both of which showed higher values of ${ }^{137} \mathrm{Cs}$ activities in wild boar muscle from the Novohradské Mountains for the winter season compared to the summer season $(P=0.000)$ (Fig. 4).

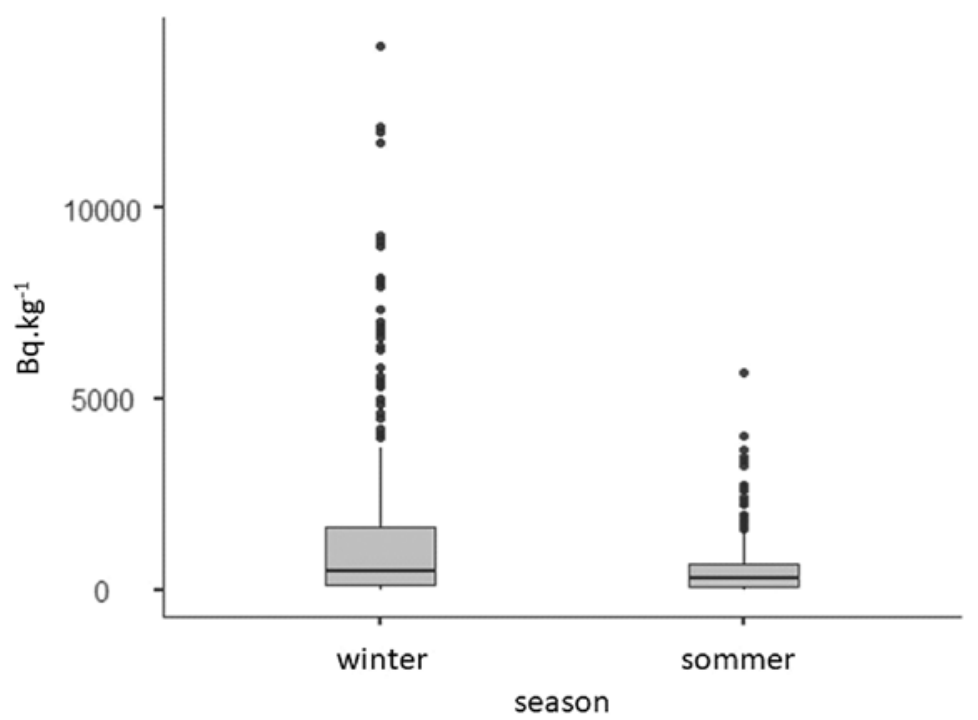

Fig. 4. Statistical distributions of the oxidative stress index (OSI) values (Saphiro-Wilk test $P<0.0001)$

\section{Discussion}

Ten years ago, increased caesium activity in hunted wild boar meat was repeatedly detected in locations of Šumava national park (Bohemian Forest) and Šumava protected area in Plzeň region. Based on above mentioned findings and targeted monitoring in southwest part of the Czech Republic it was ordered to monitor continuously ${ }^{137} \mathrm{Cs}$ activity in designated areas (Latini 2011; Kouba at al. 2013).

Due to the relatively short half-life of ${ }^{134} \mathrm{Cs}$ ( 2 years) and smaller deposition, the activities of this radionuclide in game meat are non-significant and contribution of ${ }^{134} \mathrm{Cs}$ to the effective dose received by game consumers may be neglected (Rachubik 2008). Consequently, the ${ }^{134} \mathrm{Cs}$ concentration was not assessed in this study. One of the monitored locations of the ${ }^{137} \mathrm{Cs}$ activity was also the Novohradské Mountains. The monitoring of the ${ }^{137} \mathrm{Cs}$ activity was also done in neighbouring states, e.g. in the German states of Bavaria (Hecht 2001; Fielitz 2005; Fielitz et al. 2009; Steiner and Fielitz 2009; Kienzle et al. 2013), Rhineland - Palatinate (Hohmann and Huckschlag 2005), or Baden Württemberg (Zibold et al. 2001; Semizhon et al. 2009); furthermore, in Austria (Strebl and Tataruch 2007), Poland (Rachubik 2008) and the more distant Croatia (Vilic et al. 2005). 
Most of the studies state that contamination of wild boars by radiocaesium stays on a relatively high level and shows a slower decrease or even remains constant over time (Zibold et al. 2001; Strebl and Tataruch 2007; Škrkal et al. 2015).

This fact was confirmed by Latini (2011) in the beginning of 2011 by findings of high values of caesium sum mass activity in samples of game meat: old boar - $4029 \mathrm{~Bq} \cdot \mathrm{kg}^{-1}$ $\left(4028 \mathrm{~Bq} \cdot \mathrm{kg}^{-1}{ }^{137} \mathrm{Cs}\right.$ and $1 \mathrm{~Bq} \cdot \mathrm{kg}^{-1}{ }^{134} \mathrm{Cs}$ ) as well as another three from four adult boars (2065 Bq.kg-1 1644 Bq. $\mathrm{kg}^{-1}, 1774$ Bq. $\mathrm{kg}^{-1}$ ). Wild boars were hunted at locations in the territorial departments of the Bohemian Forest, Prášily and Srní.

Similar observations were reported by Kouba et al. (2013), based on samples collected in December 2012 and early 2013 in the South Bohemian region. The survey was carried out in two parts. In December 2012, increased caesium sum activities $\left({ }^{134} \mathrm{Cs}\right.$ a $\left.{ }^{137} \mathrm{Cs}\right)$ were detected in game meat samples from two hunting grounds in the Novohradské Mountains (Kraví hora $-2776 \mathrm{~Bq} \cdot \mathrm{kg}^{-1}$ and Jelení Hřbet $-6998 \mathrm{~Bq} \cdot \mathrm{kg}^{-1}$ ). In the second phase at the beginning of 2013, increased caesium sum activities were detected on three other hunting grounds in the Novohradské Mountains (hunting ground Vysoká - average activity of $2947 \mathrm{~Bq} \cdot \mathrm{kg}^{-1}$, hunting ground Rychnov u Nových Hradů - average activity of $6935 \mathrm{~Bq} \cdot \mathrm{kg}^{-1}$, and hunting ground Zofín - average activity of $3569 \mathrm{~Bq} \cdot \mathrm{kg}^{-1}$ ).

Based on further findings of the analysis of game meat samples from wild boars hunted in the Novohradské Mountains in which above-limit caesium sum activities were proved, in compliance with veterinary legislation the relevant Regional Veterinary Administration ordered the emergency veterinary precautions. The aim of the ordered emergency veterinary precautions was to ensure that contaminated products of animal origin would not be consumed. Determinative criteria for ordering emergency veterinary precautions were repeated findings of above-limit values of ${ }^{137} \mathrm{Cs}$ in wild boar meat. Game meat with above-limit values of ${ }^{137} \mathrm{Cs}$ is unsafe for human consumption. From the point of view of the food law, food must not be offered on the market when unsafe. To determine whether a food is unsafe, the following should be taken into account: a) presumable immediate or short term or long term effects of particular food not only on the health of an individual who consumes it but also on the health of next generations; b) presumable cumulative toxic effects; c) particular health sensitivities of a specific category of consumers, if this food is intended for this category of consumers. In deciding whether a food is not fit for human consumption, also the question of whether it is due to contamination by extraneous or another substance should be taken into (Council Regulation [EC] No. 178/2002 of the European Parliament and of the Council).

In terms of limit values (maximum permissible level of radioactive contamination in food) in the Czech Republic, in 2012 a discussion was initiated regarding an expert evaluation of the sum limit of $600 \mathrm{~Bq} \cdot \mathrm{kg}^{-1}$ for caesium in the so called other food, including wild boar meat. The main reason for such discussion was the absence of national legislation which would strictly define a maximum permissible level of the ${ }^{137} \mathrm{Cs}$ mass activity in food. In its statement No. SÚJB/RO/21759/2012 of 23 august 2012, the State Office for Nuclear Safety said it considered it reasonable to apply a maximum permissible level of $600 \mathrm{~Bq} \cdot \mathrm{kg}^{-1}$ for ${ }^{137} \mathrm{Cs}$ mass activity for the regulation of wild boar meat production and marketing, as laid down in the Council Regulation (EC) No. 733/2008 related to the import of food from third-world countries.

Because of fair food assessment and population radiation regulation SÚJB did not find any reasons to set for placing food on the market other limit value than limit value valid for food imported to the Czech Republic. So SÚJB by its statement declared ${ }^{137} \mathrm{Cs}$ mass activity $600 \mathrm{~Bq} \cdot \mathrm{kg}^{-1}$ as a maximum permissible level of radioactive contamination of food. That implies this level of radioactive contamination of food can be considered as a relative value corresponding to scientific knowledge from the point of view of the food law. 
The present study analyzes collected samples of game meat of wild boars hunted in the southern parts of the Bohemian Forest massif of Novohradské Mountains, including the hunting grounds Kraví Hora, Jelení Hřbet, Vysoká, Rychnov u Nových Hradů and Žofín. The mentioned localities correspond to previously described forest ecosystems exhibiting higher ${ }^{137} \mathrm{Cs}$ specific activity in forest fruits, mushrooms, and game meat, which were exposed to contaminated airborne masses over the Czech Republic in April 1986 (Hůlka and Malátová 2006).

The seven-year study monitoring the ${ }^{137} \mathrm{Cs}$ mass activity in samples of game meat from wild boars hunted in the Novohradské Mountaits (Table 1) concludes that $36.4 \%$ of the samples exceeded the limit of $600 \mathrm{~Bq} \cdot \mathrm{kg}^{-1}$. According to the food law, one in three hunted wild boars is not fit for human consumption.

In a pilot study in the monitoring period from 2012 to 2014 (Kouba et al. 2015), 196 meat samples of wild boar hunted in the Novohradské Mountains area were analysed; the mean ${ }^{137} \mathrm{Cs}$ activity was $247 \mathrm{~Bq} \cdot \mathrm{kg}^{-1}$, the median $320 \mathrm{~Bq} \cdot \mathrm{kg}^{-1}$, and the maximum 14,252 $\mathrm{Bq} \cdot \mathrm{kg}^{-1}$. With respect to the above mentioned measured ${ }^{137} \mathrm{Cs}$ mass activity in hunted wild boar meat samples (Table 2), it can be concluded that in comparison with the presented study we observe a slightly increasing tendency in the Novohradské Mountains area. The cause of this fact can also be the finding that there is a strong increase in the population of wild boar, especially in the south-east foothills of the Bohemian Forest (Bieber and Ruf 2005; Forejtek et al. 2013). In this species we can also notice tendency to spread progressively to higher parts of Bohemian Forest.

Wild boars have been recently seen in places where they had not been seen before which is a problem also in the mountain regions (Vodňanský 2011; Wirthner et al. 2012). A limiting abiotic factor for the wild boar habitat is not so much the altitude but rather the length of the period of snow cover and sub-zero temperatures, when the soil is so frozen that wild boars cannot dig out feed (Wolf and Rakušan 1994; Markov et al. 2019). However, this argument does not correlate with our hypothesis that mainly in the Novohradské Mountains for the past few years snow cover did not last as long as usual, and higher temperatures mostly in the winter season allowed wild boars to move to higher places in respect to altitude (Fig. 3, Table 5).

Considering the aspect of season and the above mentioned ${ }^{137} \mathrm{Cs}$ activity values of hunted wild boar meat, significant variations come out of the analysis, when ${ }^{137} \mathrm{Cs}$ activities during the winter season (November-April) were higher. Higher measured values are also evident after taking into account the time of year. There is an evident increase in measured values from December till May (Figs 1 and 4).

Our results correlate with the findings presented by Hohmann and Huckschlag (2005) in their thesis about seasonality. It says that the ${ }^{137} \mathrm{Cs}$ activity in wild boar is partly influenced by season because of different feed compositions during the year (Fielitz 1992; Haffelder 1995; Zibold et al. 2001). In the south-eastern German state of Bavaria, studies on wild boars in contaminated areas showed the ${ }^{137} \mathrm{Cs}$ activity in muscle tissue reaching the peak value between January and April and beginning to descend mostly in May or July, with a minimum in October-December (Hecht 2001; Schwind et al. 2002). This phenomenon is accounted for by higher availability of field crops that are little contaminated in the summer season, and not much contaminated forest trees in autumn, in contrast to the winter season, when mainly in forested areas, higher intake of more contaminated forest feed results in increased ${ }^{137} \mathrm{Cs}$ activity in muscle tissue (Hohmann and Huckschlag 2005). A statistically significant seasonal effect was observed in wild boars with the highest activities measured in winter. Worse availability of natural feed (chestnuts, acorns, beechmast), which makes wild game to look for feed (often mushrooms) bellow the ground, gave reasons for higher winter and spring activities in wild boars (Š krkal et al. 2015). The results are also partly in compliance with a study in which the maximum ${ }^{137} \mathrm{Cs}$ activity 
was observed in January, February, and March, whereas the minimum ${ }^{137}$ Cs activity was observed in September, October, and November (Semizhon et al. 2009).

It is assumed that radioactive caesium transfer from soil through plants and mushrooms into animals is much higher in forest ecosystems than in the agricultural environment, and our findings in the Novohradské Mountains correspond with this assumption. Game feeding on forest products absorb radioactive caesium at higher quantities compared to farm animals feeding on agricultural fodder (Rachubik 2008). Increased ${ }^{137} \mathrm{Cs}$ concentrations in wild boar was found to reflect the consumption of large amounts of mushrooms, especially deer truffles (Elaphomyces granulatus), which contain high concentrations of ${ }^{137} \mathrm{Cs}$ (Hohmann and Huckschlag 2005; Strebl and Tataruch 2007; Rachubik 2008; Steiner and Fielitz 2009; Dvořák et al. 2010; Kapala et al. 2015). In addition to deer truffles, other forest products can also be potential contaminants. For example, blueberries (Vaccinium myrtillus), ferns (Pteridium aquilinium) or fungi belonging to the Boletaceae (Xerocomus badius), which are very common in the monitored area, can reach elevated ${ }^{137} \mathrm{Cs}$ levels. However, considering the ${ }^{137} \mathrm{Cs}$ concentrations in those products, deer truffles can be considered as the main source of ${ }^{137} \mathrm{Cs}$ contamination of wild boars in the monitored area (Hohmann and Huckschlag 2005; Dvořák et al. 2006; Rachubik 2008; Dvořák et al. 2010).

According to various authors, factors that influence contamination of wild boar meat include local radiocaesium contamination, availability of feed, and biotope type (forest only or access to field crops) (Fielitz 2005; Hohmann and Huckschlag 2005; Vilic et al. 2005; Semizhon et al. 2009). Majority of findings are in agreement with the conclusions of our research of the ${ }^{137} \mathrm{Cs}$ activity in the meat of wild boars hunted in the Novohradské Mountains area.

One of the basic provisions of the food law is the applicability of the hazard analysis principle in relation to achieving a high level of protection of human health and life. The State Office for Nuclear Safety set the ${ }^{137} \mathrm{Cs}$ mass activity of $600 \mathrm{~Bq} \cdot \mathrm{kg}^{-1}$ as the maximum permissible level of radioactive contamination of food in the Czech Republic. It is therefore possible to consider this level of radioactive contamination of food as a relevant value corresponding to scientific knowledge from the point of view of the food law and to consider all food that exceeds this limit as unsafe. Based on our monitoring of the ${ }^{137} \mathrm{Cs}$ mass activity in the meat of wild boars hunted in the Novohradské Mountains, it is justified to order emergency veterinary precautions, which aim to eliminate game meat with abovelimit ${ }^{137} \mathrm{Cs}$ activity values from the food chain.

\section{References}

Act No. 166/1999 Coll., On Veterinary Care and Amending Certain Related Laws (Veterinary Act), Volume 57, Ministry of the Interior, Praha, pp. 3122-3150

Bieber C, Ruf T 2005: Population dynamics in wild boar Sus scrofa: ecology, elasticity of growth rate and implications for the management of pulsed resource consumers. J Appl Ecol 42: 1203-1213

Council Regulation (EC) No. 733/2008 of 15 July 2008 on the conditions governing imports of agricultural products originating in third countries following the accident at the Chernobyl nuclear power station. Official Journal of the European Union, Luxemburg, pp. 198-204

Dvořák P, Kunová V, Beňová K, Ohera M 2006: Radiocesium in mushrooms from selected locations in the Czech Republic and the Slovak Republic. Radiat Environ Bioph 45: 145-151

Dvořák P, Snášel P, Beňová K 2010: Transfer of radiocesium into wild boar meat. Acta Vet Brno 79: 85-91

Fielitz U 1992: Ausbreitung und Transfer von Radiocaesium Entlang des Pfades Boden-Pflanze-Reh in zwei unterschiedlichen Ökosystemen (in German, Dispersion and transmission of radiocesium along the soil-plantroe deer path in two different ecosystems). Universität Göttingen, Göttingen, $81 \mathrm{p}$.

Fielitz U 2005: Untersuchungen zum Verhalten von Radiocäsium in Wildschweinen und anderen Biomedien des Waldes (in German, Radiocesium in wild boars and their forest ecosystem). Abschlußbericht zum Forschungsvorhaben. Bundesministeriums für Umwelt, Naturschutz und Reaktorsicherheit, Bonn, 101 p.

Fielitz U, Klemt E, Strebl F, Tataruch F, Zibold G 2009: Seasonality of ${ }^{137} \mathrm{Cs}$ in roe deer from Austria and Germany. J Environ Radioactiv 100: 241-249 
Forejtek P, Červený J, Vodňanský M 2013: Problematika tetřevovitých v česko-bavorském př́hraničí (in Czech, The issue of grouse in the Czech-Bavarian border area). Institut ekologie zvěre Veterinární a farmaceutické univerzity v Brně, Brno, 88 p.

Haffelder M 1995: Radiocäsium im Waldökosystem des Hinteren Bayerischen Waldes nach dem Reaktorunfall von Tschernobyl unter besonderer Berück-sichtigung der Äsungspflanzen des Schalenwildes (in German, Radiocesium in the forest ecosystem of the Upper Bavarian Forest after the Chernobyl accident regarding the food chain of ungulates). Universität Ulm, Ulm, $178 \mathrm{p}$.

Hecht H 2001: Der lange Schatten von Tschernobyl. Forschungsreport 1: 19-23

Hohmann U, Huckschlag D 2005: Investigation on the radiocesium contamination of wild boar (Sus scrofa) meat in Rhineland-Palatinate: a stomach conet analysis. Eur J Wildlife Res 51: 263-270

Hůlka J, Malátová I 2006: Radiační situace v České republice, přehled hlavních výsledků měření a opatření (in Czech, Radiation situation in the Czech Republic, overview of the main measurement results and measures). National Radiation Protection Institute, Praha, 14 p.

Kapala J, Mnich K, Mnich S, Karpinska M, Bielawska A 2015: Time-dependence of ${ }^{137}$ Cs activity concentration in wild game meat in Knyszyn Primeval Forest (Poland). J Environ Radioactiv 141: 76-81

Kienzle E, Reddemann J, Swart D, Swart A, Draxler B, Morfeld P 2013: Effect of ammoniumiron-hexacyanoferrate and of the covariates age, gender, weight, season and calendar time on radiocaesium contamination of wild boars living in the wild in Bavaria. J Anim Physiol An N 97: 495-501

Kouba F, Bílý R, Malena M, Drápal J, Hanzal V, Vernerová K 2015: Sledování aktivity radiocesia $\mathrm{Cs}^{137}$ ve zvěřně divočákủ v jihozápadní ćásti České republiky (in Czech, Monitoring of $\mathrm{Cs}^{137}$ activity in wild boars in the southwestern part of the Czech Republic). In: Hygiena alimentorum XXXVI. Štátna veterinárna a potravinová správa Slovenskej republiky, Bratislava, pp. 57-59

Kouba F, Cipínová E, Drápal J, Hanzal V, Malena M, Vernerová K 2013: The radioactivity monitoring of wild boars in the South Bohemian Region. Maso International 2: 151-154

Latini T 2011: Výskyt radioaktivity u divokých prasat (in Czech, Occurrence of radioactivity in wild boars). Maso 22: $24-26$

Markov N, Pankova N, Morelle K 2019: Where winter rules: Modeling wild boar distribution in its north-eastern range. Sci Total Environ 687: 1055-1064

Rachubik J 2008: Radioceasium in Polish game meat. B Vet I Pulawy 52: 399-403

Regulation (EC) No 178/2002 of the European Parliament and of the Council of 28 January 2002 laying down the general principles and requirements of food law, establishing the European Food Safety Authority and laying down procedures in matters of food safety. Official Journal of the European Union, Luxemburg, pp. 463-486

Semizhon T, Putyrskaya V, Zibold G, Klemt E 2009: Time-dependency of the 137Cs contamination of wild boar from a region in Southern Germany in the years 1998 to 2008. J Environ Radioactiv 100: 988-992

Schwind KH, Münch S, Jira W 2002: Bestimmung der Änderung der flächenmäßigen Verteilung der staatlichen Jagdgebiete Bayerns, in denen Radiocäsiumaktivitäts konzentrationen $>600 \mathrm{~Bq} / \mathrm{kg}$ Frischmasse (FM) in Rot-, Reh-, Schwarz- und Gamswild auftreten können (in German, Changes in the territorial distribution of state hunting grounds in Bavaria, with radiocesium activity values $>600 \mathrm{~Bq} / \mathrm{kg}$ in red deer, roe deer, wild boars and chamois). Federal Research Centre for Nutrition and Food, Kulmbach, $118 \mathrm{p}$.

Steiner M, Fielitz U 2009: Deer truffles - the dominant source of radiocaesium contamination of wild boar. Radioprotection 44: 585-588

Steinhauser G, Brandl A, Johnson T 2014: Comparison of the Chernobyl and Fukushima nuclear accidents: A review of the environmental impacts. Sci Total Environ 470-471: 800-817

Strebl F, Tataruch F 2007: Time trends (1986-2003) of radiocesium transfer to roe deer and wild boar in two Austrian forest regions. J Environ Radioactiv 98: 137-152

Škrkal J, Rulík P, Fantínova K, Mihalík J, Timková J 2015: Radiocaesium levels in game in the Czech Republic. J Environ Radioactiv 139: 18-23

Vilic M, Barisi D, Kraljevic P, Lulic S 2005: ${ }^{137} \mathrm{Cs}$ concentration in meat of wild boars (Sus scrofa) in Croatia a decade and half after the Chernobyl accident. J Environ Radioactiv 81: 55-62

Vodňanský M 2011: Vývoj populace černé zvěře v České republice a dalších zemích Evropy (in Czech, Development of the wild boar population in the Czech Republic and other European countries). In: Černá zvěřstále aktuální problém. Středoevropský institut ekologie zvěře, Brno, pp. 11-24

Wirthner S, Schütz M, Page-Dumroese D, Busse M, Kirchner J, Risch A 2012: Do changes in soil properties after rooting by wild boars (Sus scrofa) affect understory vegetation in Swiss hardwood forests? Can J Forest Res 42: $585-592$

Wolf R, Rakušan C 1994: Černá zvěř (in Czech, Wild boars). Státní zemědělské nakladatelství, Praha, 204 p.

Zibold G, Drissner J, Kaminski S, Klemt E, Miller R 2001: Time-dependence of the radiocaesium contamination of roe deer: Measurement and modelling. J Environ Radioactiv 55: 5-27 